\title{
Characteristics of a new variant of rabbit haemorrhagic disease virus - RHDV2
}

\author{
DOMINIKA BęBNOWSKA, ${ }^{1}$ PAULINA NiEDŹWIEDZKA-RYSTWEJ ${ }^{2}$
}

\author{
${ }^{1}$ Student's Scientific Circle of Immunology; Institute of Biology, University of Szczecin, Felczaka 3c, 71-412 Szczecin, Poland \\ 2 Institute of Biology, University of Szczecin, Felczaka 3c, 71-412 Szczecin, Poland \\ Corresponding author, e-mail: paulina.niedzwiedzka-rystwej@usz.edu.pl
}

Keywords rabbit haemorrhagic diesease virus, RHDV2, GI. 2

Abstact RHD (Rabbit Haemorrhagic Disease) is an etiologic agent that causes viral haemorrhagic disease of rabbits, which is also referred to as rabbit plague. The desire to explore knowledge about this pathogen in the world results not only from its similarity to human hemorrhagic fevers, for which RHDV can be considered as a good research model. It is also important that with myxomatosis, rabbit plague is the most severe viral disease of these animals. Describing the classic RHDV virus, followed by RHDVa, which is considered the first described antigenic variant of the RHD virus, allowed to become familiar with the information that until now constituted the basic building block of the control of viral haemorrhagic disease of rabbits in the world. However, the attributes of RHDV2, characterized only in 2010, differ significantly from the specifics of RHDV strains known to date. What's more, the global expansion of this pathogen has significantly changed the RHD image, the methods of its identification, control and eradication. The completely changed face of the virus that causes rabbit plague causes that the belief about full supervision over RHD is now obsolete.

\section{Charakterystyka nowego wariantu wirusa choroby krwotocznej królików - RHDV2}

Słowa kluczowe

Streszczenie wirus choroby krwotocznej królików, RHDV2, GI. 2

Wirus RHD (Rabbit Haemorrhagic Disease) stanowi czynnik etiologiczny wywołujący wirusową chorobę krwotoczną królików, którą określa się również jako pomór. Chęć do zgłębiania wiedzy na temat tego patogenu na świecie wynika nie tylko z jego podobieństwa do ludzkich gorączek krwotocznych, dla których RHDV może być uznany za dobry model badawczy. Istotny jest także fakt, że wraz z myksomatozą, pomór królików to najdotkliwsza choroba wirusowa tych zwierząt. Opisanie klasycznego wirusa RHDV, a następnie RHDVa, który uznawany jest za pierwszy opisany wariant antygenowy wirusa RHD, pozwoliło na zaznajomienie się z informacjami, które dotychczas stanowiły podstawowy budulec bastionu dla kontroli nad wirusową chorobą krwotoczną królików na świecie. Jednakże cechy scharakteryzowanego dopiero w 2010 roku RHDV2 znacznie odróżniają się od specyfiki znanych do tej pory szczepów RHDV. Co więcej, globalna ekspansja tego patogenu znacząco zmieniła 
obraz RHD, metody jej identyfikacji, kontroli i zwalczania. Całkowicie zrewoltowane oblicze wirusa wywołującego pomór królików powoduje, że przekonanie o pełnym dozorze nad RHD jest już przestarzałe.

\section{Introduction}

RHD (Rabbit Haemorrhagic Disease) is an etiologic agent that causes viral haemorrhagic disease of rabbits, also called plague. Rabbits, in addition to being a key element of the economy of many countries, also exist as an important link in the trophic chains of the Mediterranean ecosystems. As laboratory animals, they are widely used in various types of research and diagnostic analyzes (Abrantes, van der Loo, Le Pendu, Esteves, 2012). The huge losses in their numbers, which started the first documented outbreak of the RHD epidemic in China in 1984 (Liu, Xue, $\mathrm{Pu}$, Quian, 1984), led to serious economic losses as well as decline in the number of endangered species for which rabbits form the basis of food. This situation led, among others, to the fact that RHDV has become the object of research around the world (Abrantes et al., 2012).

It was observed that the experimental infection of rabbits with this pathogen is a research model in the pursuit of knowledge about human hemorrhagic fevers. The key fact that allows this factor to be used is that the rabbit hemorrhagic diseases virus infections in rabbit and human are characterized by similar clinical features, including the equally rapid course of infection. These concordants mean that research into rabbit fever virus provides a perspective for the development of new effective methods of fight and prevention in the future of human hemorrhagic fevers (Tokarz-Deptula, Deptula, Kesy, 2002). In addition, pathomorphological changes in the liver, observed post-surgically among the experimentally infected RHDV rabbits, are the subject of research in the failure of this organ, which refers to the pathogenesis of viral hepatitis observed in humans, as well as in determining the effectiveness of hepatoprotective agents (Pazdzior, Otrocka-Domagala, Rotkiewicz, Drzewiecka, 2011).

In addition, RHDV is a virus whose genetic material is a single strand of RNA with positive polarity, and RNA viruses are characterized by high genetic variability caused by frequent mutations within the strand encoding genetic information (Fitzner, Niedbalski, 2017). The consequence of such phenomena is diversity among isolated strains of viruses, which is observed in the case of viruses that cause haemorrhagic disease of rabbits. Thanks to this, it is also possible to consider the factors that cause RHD as a tool for research conducted to expand the current state of knowledge about RNA viruses, among which there are many pathogens of humans and other mammals.

The purpose of the work is to characterize a relatively recently registered RHDV2 virus, the features of which differ significantly from the specifics of the previously known RHDV strains. The economic, epidemiological and diagnostic situation will be evaluated, which will allow conclusions to be drawn about the threats that may be caused by the emergence and expansion of the RHDV2 in the world.

\section{History of appearance in RHDV2}

Since the end of 2010, deaths have been reported among vaccinated and non-vaccinated rabbits in Northwest and Northern France (Le Gall-Recule et al., 2011). Sectional studies of dead animals reveal various changes in many organs, characteristic of infections that trigger RHDV. The factor responsible for these incidents was subjected to many analyzes and that allowed for demonstration its kinship with the RHDV and RHDVa virus (Le Gall-Recule et al., 2011). 
However, never previously observed properties in any RHDV strain (neither RHDV nor RHDVa), led to the conclusion that it belongs to a different gene group and exists as a virus that causes haemorrhagic disease of rabbits (Le Gall-Recule et al., 2011). This factor was also diagnosed by another research team in Spain (Dalton, Nicieza, Abrantes, Esteves, Parra, 2014). In 2011, in this country, people started to observe the emergence of powerful outbreaks of RHD infection, adults as well as juveniles. The new strain, called RHDV-N11, was quickly transferred to many Spanish provinces, replacing the predominant G1 RHDV genotypes. His presence led to huge losses in the rabbit industry, putting him in a serious economic disadvantage (Dalton et al., 2014). The results of the analyzes carried out, showed a significant phylogenetic distance of strain led to introduce the new term for RHDV-N11, namely RHDVb, which is assigned to the RHDVb group (Dalton et al., 2012). Next, reports of a new strain have appeared in the summer of 2011 in Italy. The incident occurred in the north-eastern part of this country in one of the industrial farms (Le Gall-Recule et al., 2013). At the beginning of the next year, outbreaks of disease began to be observed also among wild populations (Velarde et al., 2017). Based on facts regarding the unique characteristics of these strains, the pathogen was called RHDV2 (Le Gall-Recule et al., 2013). The extent of this lagovirus throughout the Iberian Peninsula confirms its appearance in November 2012 also in Portugal, where he was responsible for epidemics among wild rabbit populations (Abrantes et al., 2013). The presence of the virus again posed a threat to the endemic species inhabiting this area, i.e. Iberian lynx and the Iberian imperial eagle (Carvalho et al., 2017; Silverio et al., 2018). RHDV2 have covered a relatively large part of the continent quite quickly. In May 2013, he was diagnosed, among others in Sweden, in samples taken during fieldwork (Neimanis et al., 2018). List of countries reporting cases of infections issued in Great Britain (Westcott et al., 2014). and Scotland in 2014 (Baily, Dagleish, Graham, Maley, Rocchi, 2014), Germany (information FLI- Friedrich Loeffler Institut, 2013), as well as reports submitted to the World Organization for Animal Health, Norway (OIE WAHIS, 2014), Switzerland (OIE WAHID, 2016a), Finland (OIE WAHIS, 2016b) and Denmark (OIE WAHIS, 2016c) (Velarde et al. 2017). In Tenerife, virus has been observed since 2015 (Martin-Alonso, Martin-Carrillo, Garcia-Livia, Valladares, Foronda, 2016). The detection of the RHDV2 virus in Poland is associated with the study of rabbits that died in September 2016 on a farm in the village of Reduchów near Zduńska Wola and individuals who died in June 2017 in the West Pomeranian Voivodeship (Fitzner, Niedbalski, 2018).

It was also found in studies conducted in slow-breeding rabbit populations and individuals from farms, that this factor is characterized by a tendency to displace the classical RHD variant both in Tenerife and also in the Iberian Peninsula (Le Pendu et al., 2017; Silverio et al., 2018; Velarde et al., 2017), as well as in France and the Azores (Duarte et al., 2015; Martin-Alonso et al., 2016). The Azores are also places where RHDV2 was first diagnosed outside the European continent in 2014 (Duarte et al., 2015). The virus appeared in Australia in Canberra in May 2015 (Hall et al., 2015), where it also appeared in the southern part of the country, when it was detected on December 1, 2015 (Peacock et al., 2017). The presence of the pathogen has led to a reduction in the number of rabbits by about $80 \%$ in this area, which in fact can have a positive impact on the environment here, due to the recognition of these animals as pests (Mutze et al. 2018). In 2016, the presence of RHDV2 was also confirmed in Oceania and Canada (Rouco, Aguayo-Adan, Santoro, Abrantes, Delibes-Mateos, 2019). The RHDV2 virus was also detected in Africa, where it was confirmed in 2015 in Benin, Tunisia (Rahali, Sghaier, Kbaier, Zanati, Bahloul, 2019), and also in 2017 in Morocco (Lopes, Rouco, Esteves, Abrantes, 2019). Since 2017, RHDV2 has been also reported in New Zealand and the United States. In 2018, the virus appeared in Israel (Rouco et al., 2019). 


\section{RHDV2 - a new member of the genus Lagovirus}

Phylogenetic analyzes as a basic tool for determining the relationship of the tested materials are an important point in the process of identifying viral genetic material isolated posthumously from infected rabbits, as evidenced by research carried out by many scientific teams (Abrantes et al. 2013; Camarda et al., 2014; Dalton et al., 2015, Dalton et al., 2018; Dzialo, Deptula, 2015; Fitzner, Niedbalski, 2017; Le Gall-Recule et al., 2003, 2011; Lopes et al., 2015, 2018). The latest nomenclature aimed at organizing the naming of RHDV, RHDVa and RHDV2/b, based on phylogenetic compounds within the Lagovirus genus, has classified RHDV2 as a separate genotype called GI.2 (Le Pendu et al., 2017). However, the research already carried out at the beginning of the appearance of the putative variant revealed that it is genetically separated from the classical RHDV and RHDVa, because the homology between them is only $87.5 \%$ (Le Gall-Recule et al., 2011). It remains inso facto closer associated with non-pathogenic rabbit calicivirus RCV (Dalton et al.,2012; Dzialo, Deptula, 2017). Based on the studies of the structural gene sequence encoding the VP60 and VP10 proteins, it was concluded that it constitutes a separate genetic group (Le GallRecule et al. 2013), located between apatogenic strains RCV-A1 and weakly pathogenic MRCV, which confirms close relation to RCV (Fitzner, Niedbalski, 2017). In addition, the classification of the variant as a separate member of the Lagovirus family confirms its distinctive from classical RHDV and RHDVa structure, encompassing amino acid differences in the P domain of the capsid protein (Leuthold, Dalton, Hansman, 2015) affecting the specificity of HBGA- (Histo-Blood Group Antigen) binding, which may be associated with its antigenicity (Le Gall-Recule et al., 2013). Antigenic characterization is another aspect that distinguishes RHDV from each other and has an impact on the classification of variant 2 as a separate position within the species (Le Gall-Recule et al., 2013). These discrepancies have been demonstrated, inter alia, in studies via monoclonal antibodies (mAbs) in the Dot Blot technique, as well as hemagglutination reactions (Dalton et al., 2012). The antigenic differences exhibited by RHDV2 and RHDV were also confirmed by the generation and evaluation of RHDV2 specific VLP particles (Barcena et al., 2015). The fact that only a partial cross-protection within the variants of the virus has been disclosed. It is noted that the observed lethal course of infection among individuals who had previously had RHD disease, as well as the lack of efficacy of vaccines used against RHDV, confirms the individual serotype of the new pathogen (Dalton et al., 2012; Le Gall-Recule et al., 2013). Also significant is the variability in the course of RHDV2-induced disease, mainly concerning the duration of the disease, mortality, as well as the increased frequency of sub-acute/chronic forms of the disease (Fitzner, Niedbalski, 2017; Le Gall-Recule et al., 2013). It is worth noting that the source of the appearance of RHDV2 is not fully understood, because there are many hypotheses trying to solve this dilemma, among others the hypothesis of evolution from another lagovirus, as well as the genetic jump hypothesis. However, some molecular data cross the assumption that RHDV2 is the result of genetic evolution of a known representative of the Lagovirus family, which causes that genesis of the variant is still questioned (Le Gall-Recule et al., 2013).

\section{Characteristics of RHDV2}

RHDV2 virus molecule is not different compared to the previously described classical variant of the RHD virus. The new virus genome is analogously contained in two open reading frames (ORFs), where ORF1 encodes unstructured genes and participates in the synthesis of the VP60 protein, while ORF2 encrypts the genes responsible for the structural VP10 protein (Mahar et al., 
2017). The average amino acid homology between viruses, which is $89.2 \%$, drops to $60 \%$ the comparison is limited to the 7 regions of the $\mathrm{P}$ domain, that show the highest variability. Thanks to analyzes in crystallographic resolution of P domain of VP60 protein, it was possible to show structural differences between pathogens These discrepancies, in spite of the relatively similar design of the helix, relate to the deployment of the P1 subdomain of helix, which is more displaced. There is also a different conformation in the P2 domain, on the surface of which on the elongated loops there are amino acid changes conditioning the differences between RHDV2 and RHDV (Barcena et al., 2015).

\section{Epidemiology of RHDV2}

Natural and experimental RHDV infections observed in the past always concerned only one characteristic host - the European rabbit Oryctolagus cuniculus. The emergence and spread of RHDV2 strains in the environment revealed that it has the ability to infect a much wider range of species, not limited to $O$. cuniculus, which is a real phenomenon within lagovirus. This factor was diagnosed as the cause of acute epidemics among different Leporidae. In Sardinia, cases of disease similar in terms of symptoms to EBHS have been reported, among individuals belonging to Lepus capensis (Puggioni et al., 2013). Laboratory analyzes using a direct haemagglutination test, using human blood cells, an ELISA test, as well as sequencing of the VP60 protein genetic code, absolutely ruled that the causative agent of these epizootics is RHDV2 (Puggioni et al., 2013). Isolated cases of disease caused by the new lagovirus have also been described among Lepus corsicanus (Camarda et al., 2014). A similar situation was observed for European brown hares Lepus europaeus on the European continent (Hall et al., 2018; Velarde et al., 2017), as well as in Australia (Hall et al., 2017). Despite pathological changes consistent with EBHSV, described during performed autopsies of dead animals, examination of isolated genetic material by means of RT-PCR and tests based on specific monoclonal antibodies-mAb, showed the presence of RHDV2 virus in samples (Velarde et al., 2017). The analysis of data on the impact of the virus on different lagomorphs populations revealed that this pathogen is highly pathogenic to European rabbit (O. cuniculus), European hare (L. europaeus) and to L. capensis, while lower pathogenicity is characterized by towards $L$. corsicanus. There were also cases of infection of L. timidus (Neimanis et al., 2018) however, the level of virulence of RHDV2 strains against this species has not been determined (Le Gall-Recule et al., 2017). It is also worth mentioning that this virus causes mortality at a similar level, both for young and adults. The sex of animals is irrelevant to the virulence of the virus, which is analogous to the situation observed with infection caused by classical RHDV (Rouco et al., 2018).

Transmission of the RHDV2 virus can be described as typical, which is observed in the case of RHDV. The presence of RHDV2 has been detected also in the carcase of the Mediterranean Pine Vole (Microtus duodecimcostatus) and the White-Toothed Shrew (Crocidura russula). An experimental infection of rabbits with an inoculum obtained from said animals showed that these animals are capable of passive transmission of the virus. This finding is also confirmed by the belief that RHDV2 breaks the interspecies barrier (Calvete et al., 2019). 


\section{Immunological processes occurring during RHDV2 infection}

Studies have been carried out in which a significant participation of CD4+ and CD8+ T lymphocytes have been demonstrated in the mechanisms of specific cellular response of rabbits exposed to RHDV2 infection. This fact has also been confirmed by the increased number of these cells in a short time after the use of protective vaccination, which further induces the production of specific antibodies as humoral response mechanisms. In addition, early activation of B and $\mathrm{T}$ lymphocytes as well as macrophages was observed in animals that did not show any pathological symptoms after contact with the pathogen, which in turn leads to enhanced proinflammatory cytokine activity (Muller, Ulrich, Schinkothe, Muller, Kollner, 2019).

\section{Clinical symptoms and course of infection caused by RHDV2}

Despite some differences regarding the clinical features of RHDV2 infection as compared to RHDV, the symptoms of new pathogen infection remain consistent with the classic variant (Duarte et al., 2015). Macroscopic observations and performed autopsies showed the presence of typical changes in many organs of various species hosts. Nose bleeding and congestion of the tracheal mucosa and lungs are recorded. In addition, a foamy-bloody discharge is present in the trachea. Irregularly located pulmonary embolism, bloody ecchymosis and moderate to severe intracapillary hemorrhage is observed. The pathology of the liver refers to multifocal changes with the presence of irregular lesions in the entire parenchyma, which manifests itself in characteristic marbling discolorations. The organ is enlarged, pale and fragile, which is characteristic of RHD. Microscopic examination also reveals fat degeneration of hepatocytes and multinucleation of these cells (Abade Dos Santos et al., 2017; Capucci, Cavadini, Schiavitto, Lombardi, Lavazza, 2017; Carvalho et al., 2017; Duarte et al., 2015; Duarte et al., 2015;Lopes et al. 2014; Martin-Alonso et al., 2016;Puggioni et al., 2013;Simpson, Everest, Westcott, 2014;Velarde et al., 2017). The spleen is dark and swollen, and necrotic changes affect the red and white pulp (Puggioni et al., 2013; Velarde et al., 2017). In the kidneys, the modifications concern the epithelial lining of the proximal tubules of the nephron, which is described as necrotic (Carvalho et al., 2017; Carvalho et al., 2017; Martin-Alonso et al., 2016; Simpson et al., 2014, Velarde et al., 2017). Areas of diminished tissue and inflammation are also found in the intestinal villi of the small intestine (Abade Dos Santos et al., 2017; Duarte et al., 2015; Puggioni et al., 2013). In addition, there are haemorrhages and congestions in the heart as well as in the thymus (Duarte et al., 2015; Lopes et al. 2014). Moreover, in all animals, similar to disease caused by RHDV and RHDVa, the phenomenon of disseminated intravascular coagulation - DIC (Carvalho et al., 2017; Duarte et al., 2015) is recorded in small capillaries and pulmonary arteries.

Laboratory blood tests of two rabbits with RHDV2 infection were performed, followed by the analysis of biochemical parameters, significant changes were found within them. Unlike in the course of infection induced by classical RHD virus, low values of hepatic enzymes, including aspartate aminotransferase (AST) and alanine aminotransferase (ALT), have been found in blood serum, which may result from reduced production of these enzymes by damaged hepatocytes, or it may be effect of the short half-life of these parameters. In the case of the first rabbit there was a slight decrease in cholesterol level, hypoalbuminemia, as well as high hypoglycemia. Analysis of blood belonging to the second rabbit showed hyperglyceridemia and hypercholesterolemia in his case. Both animals showed elevated levels of gamma-glutamyltransferase (GGT), alkaline phosphatase (ALP), bilirubin and bile acids. Analysis of the electrolyte level in the case of the 
first rabbit showed moderate hypochloremia and hypokalemia. In the study, in contrast to the values observed in the case of RHDV infection, a significant increase in fibrinogen levels was demonstrated for both rabbits. It was determined that the prothrombin time (PT) and activated partial thromboplastin time (APPT) is increased, which in turn remains consistent with the results observed with the classical RHD virus (Bonvehi et al., 2019).

In the course of RHDV2 infection, as in the case of RHDV-induced infection, a reduced amount of leukocytes is observed in the liver, which together with the fact that RHD rapidly elevates the temperature above $39^{\circ} \mathrm{C}$, indicates the development of systemic inflammatory response syndrome - SIRS. It should also be mentioned that the observed phenomenon of impaired immune response is associated with necrotic changes in the spleen, progressive apoptosis and the initial increase in CD4 + and CD8 + T cells followed by a significant decrease in the number of these cells. It has been demonstrated that within 36 hours of experimental animal infection the level of total T-cells in blood decreased to approximately $50 \%$ for CD $4+\mathrm{T}$ cells and to approximately $10 \%$ of normal values for CD8 + T cells (Muller et al., 2019).

Infections caused by the RHDV2 virus, despite the similarity in the observed disease symptoms and caused by anatomopathological changes, are significantly different from those caused by classical RHDV. These discrepancies relate mainly to the duration of the disease, mortality observed, as well as the incidence of subacute and chronic forms of the disease. Experimental inoculation of laboratory animals revealed that symptoms of hemorrhagic fever started appearing 3 to 9 days after inoculation and lasted on average 5 days, which is a much longer period compared to the typical course of RHD. A decreased frequency of acute course of the disease was also noted, with an increase in the frequency of subacute and chronic forms, which were characterized on the basis of morphological symptoms (Westcott et al., 2014). It was also observed that this virus is responsible for the development of the disease not only in adult rabbits, about 40-50 days old, but also in animals under 30 days. The high virulence of RHDV2 strains confirms the finding of the development of disease, initiated under experimental conditions, in individuals aged 11 days (Dalton et al., 2014). Studies have been carried out that showed that RHDV2 is able to suppress the innate immune mechanisms associated with infection in juveniles, thanks to which progression of infection is possible (Neave et al., 2018). It was generally accepted that RHDV2 is less virulent for adult animals, since the mortality rate oscillates between 0-75\% (Rouco et al., 2018), where for classical RHDV it is above $90 \%$. The generalized value of the mortality rate for a new virus, after considering all age classes, varies between 20-50\% (Dalton et al., 2012). However, it should be noted that some strains of RHDV2 have been isolated, inducing mortality at about $80 \%$, which is similar to the typical course of RHD. This provides the supposition that recombination events in the course of virus evolution have led to the emergence of high pathogenicity strains that spread in the environment (Capucci et al., 2017) and are promoted by selective pressure (Neimanis, Larsson Pettersson, Huang, Gavier-Widen., Strive, 2018). It should be mentioned that the analysis of the condition of animals affected by rabbit haemorrhagic disease, caused by the RHDV2 virus, unambiguously determines that death of individuals in the course of the plague is a consequence of progressive multi-organ failure and described during the RHDV infecion-DIC (Capucci et al., 2017; Carvalho et al., 2017).

\section{Diagnostics and immunization}

The emergence and prevalence of RHDV2 has led to the compulsion of developing new, more sensitive diagnostic methods to identify this pathogen. The fact that the symptoms of the disease 
caused by this virus are identical to the symptoms caused by RHDV, makes the diagnosis that differentiates these factors via the pathological changes is impossible (Duarte et al., 2015, McGowan, Choudhury, 2016). It is also important that due to the high specificity of tests used against the classical RHD virus, in the confrontation with RHDV2, the results remain negative (Mahar et al., 2017). The problem in the selection of appropriate vaccines, during emerging RHD epidemics, has its solution in the application of additional diagnostic methods, allowing to determine the type of pathogen. This is mainly aimed at reducing the costs incurred, as well as increasing the effectiveness and speed of struggle in suppressing still emerging disease foci (Dalton et al., 2018). The most effective option seems to be molecular techniques related to the genome of viruses (Duarte et al., 2015). They can also be used to detect recombination events, which are an important tool for enriching knowledge about the virus (Dalton et al., 2018). Unfortunately, awareness of the effectiveness of the vaccine obtained from the liver of infected rabbits remains limited and, due to the high sensitivity of the nucleic acid, requires additional research methods (Carvalho et al., 2017). It was observed that false positive results were obtained in the polymerase chain reaction of PCR with reverse transcriptase (RT-PCR), which was provoked by genetic material of inactivated vaccine (Carvalho et al., 2017). It has now been confirmed that the described new RT-PCR tests are an effective tool for controlling the spread of the virus (Dalton et al., 2018). There were also effective modifications of this method for recognizing lagoviruses. They are successfully used in, among others Australia, where the presence of four lagoviruses is observed, i.e. GI.1c, GI.2, GI.1a-Aus and GI.1a-K5 (Le Pendu et al., 2017). These methods include multiplex RT-PCR as well as RT-qPCR in real time (Quantitative reverse transcriptase real-time PCR) (Hall et al., 2018). It should be noted that the RT-qPCR method stands out against its others with its particularly high sensitivity, as it detects only ten particles of viral RNA, and the whole process lasts under 3 hours (Duarte et al., 2015). The huge disadvantage of this type of analysis is the necessity of specialized equipment, which results in a lack of chance to diagnose the pathogen directly in the place of its presumed presence. The immunochromatographic test (LFA) has been developed as an option enabling such activities. Identification of the causative agent with LFA takes about 10 minutes, however, it is less sensitive than the RT-PCR method (Dalton et al., 2018). A big drawback of this system is the inability to analyze multiple samples simultaneously, as well as quantifying the antigen, which certainly prevents reliable control of the evolution of the disease. Another diagnostic method is the enzyme-linked immunosorbent assay (ELISA), based on the use of the mAb 2D9, which is characteristic for RHDV2. This method is characterized by $100 \%$ sensitivity and over $97 \%$ specificity for the RHDV 2 antigen, and its use positively affects the reduction of research costs and the functioning of diagnostic laboratories (Dalton et al., 2018). Unfortunately, for the efficient and effective control of the virus, there is a need for continuous improvement of diagnostic methods. The current lack of high quality rapid tests on the market, intended for use in private breeding is an extremely unfavorable situation. The time elapsing from the detection of a disease outbreak, until the results are obtained and the implementation of the procedure limiting the spread of the pathogen, is prolonged, which significantly reduces the dynamics of control over emerging RHD epizootics.

Difficulties that have arisen with the spread of infections caused by RHDV2 strains are increasing as knowledge about this pathogen increases. The observed lack of protection against the development of the disease, among individuals vaccinated against RHDV, proved the existence of immunogenic differences between viruses. In addition, the mortality observed in rabbits diagnosed with RHD that have had infection with classical strains of the virus and acquired immunity against RHDV in this way, shows the lack of cross-protection between RHDV2 and 
RHDV. This fact was of great importance for the new pathogen, which obtained such a large range in a relatively short time (Le Gall-Recule et al., 2013; Peacock et al., 2017), which is why it became urgent to develop a vaccine against RHDV2. The inactivated vaccines introduced at the beginning were prepared from rabbit liver extracts that were infected under experimental conditions. Their efficacy was assessed through studies conducted on 4-week-old female rabbits using four different strains of the RHDV2 virus (Pacho, Dahdouh, Merino, Suarez, 2016). Vaccines have been recognized in the European Union as a temporary means of combating the pathogen and controlling the epidemic. However, due to the low mortality rate generated by the virus, there were concerns about the amount of viral antigen obtained and thus the effectiveness of vaccination. As a solution to this difficulty, the use of RHDV2 VLP particles was proposed for the development of recombinant vaccines, which are an effective means of controlling the spread of the virus in the environment (Barcena et al., 2015). The recombinant RHDV2-VP1 vaccine, based on the VP1-capsid protein and produced using a baculovirus expression system, proved to be effective. It has been shown that the induction of effective immunological protection lasting for at least 14 months takes place 7 days after the immunization, while the revaccination after 21 days did not affect the prolongation of the protection period (Muller et al., 2019). Another problem in the aspect of preventive vaccination concerns the selection of a suitable vaccine. Although many sites have reported progressive replacement of classical RHDV and RHDVa variant by RHDV2 strains (Duarte et al., 2015; Lopes et al., 2014, 2015, 2017; Mahar et al., 2017; Martin-Alonso et al., 2016; Neimanis et al., 2018), there are regions where the coexistence of these pathogens is still detected. This leads to the emergence of a significant difficulty, which is the need to use two types of measures against all factors at the same time. The solution to this problem is differential diagnostics (Dalton et al., 2018).

\section{The consequences of the RHDV2 epidemic}

The RHDV2 research, and hence characterization of its unique features, on the basis of which it was considered a separate virus, prompted researchers to develop a new classification and nomenclature system within RHDV. The RHD virus belongs to the genus Lagovirus within the Caliciviridae family, which is a group of viruses without capsules with the genetic material ssRNA (+) (Dzialo, Deptula, 2017). These viruses were initially classified within the Picornaviridae family, however, taking into account the fact of their unique structure, replication strategy and physicochemical properties, they were identified as a new family. Lagoviruses form a taxon whose genetic length is $7.4-8.3 \mathrm{~kb}$, and the RNA strand is characterized by a polyadenylated 3 'end, covalently closed at the 5' end and two reading frames - ORF. In addition, compared to other members of Caliciviridae, they are distinguished by high pathogenicity and mortality among their host species (Hall, 2002). Due to the successively enriching diversity of lagoviruses, the need to reform the applied system of naming and classification of RHD virus isolates has emerged (Le Pendu et al., 2017). The analyzes carried out in 2002 allowed to describe six main genogroups among the studied RHDV strains (G1-G6). Genogroups G1-G5 contained classical RHDV, while strains of the first known antigenic variant - RHDVa were included in the G6 genogroup. The division into the above-mentioned groups (with the exception of the G6 genogroup) occurred then based on the time distribution as well as the geographical occurrence of isolated strains (Le Gall-Recule et al., 2003). The latest nomenclature suggests the division of lagoviruses based on phylogenetic analyzes based on a comparison of the full sequence of the VP60 structural protein gene. The genogroup GI and GII were thus isolated. Within the first one, among others, 
genotypes corresponding to RHDV (GI.1) and strains RHDV2/b (GI.2). In addition, the GI.1 gene group concentrates variants corresponding to the previous division, i.e. GI.1a (G6/RHDVa), GI.1b (G1), GI.1c (G2), GI.1d (G3-G5). It is worth noting that within all strains of the RHD virus one can distinguish those with varying degrees of hemagglutination capacity of human red blood cells, which constitute the predominant group, as well as strains devoid of this characteristic (Xue et al., 2016). In the division there is also a GII gene group describing the European brown hare syndrome virus - EBHSV, which together with RHDV forms a kind of Lagovirus (Le Pendu et al., 2017). The deterioration of the economic situation related to the emergence and spread in the 1980s of the classical virus causing haemorrhagic fever of rabbits, was effectively offset by the implemented preventive measures. However, with the occurrence of the first epizootics caused by the new lagovirus-RHDV2, there is still a growing economic loss in commercial and private rabbit farms, as well as in the rabbit food processing industry. It is also reported in some countries about the inconvenience of tourism, where organized rabbit hunting was a tourist asset, which certainly does not favor national economic statuses (Carvalho et al., 2017).

The expansion of rabbit haemorrhagic disease virus in the environment still causes a significant reduction in the population of the European rabbit. Recently, there has been a sharp decline in the density of individuals among rabbits, an important link in Mediterranean ecosystems. This led to a loss of balance in the trophic networks of the Iberian Peninsula. Thanks to surveys conducted in this area, it is known that the only factor that causes RHD is RHDV2. A reduced number of Spanish and Portuguese rabbits caused a simultaneous significant loss of individuals belonging to endemic species in this area for which $O$. cuniculus forms the basis of food. These changes accumulate within the critically endangered Iberian lynx and the Spanish imperial eagle (Dalton et al., 2018; Rouco et al., 2018). It was determined that the decline in the number of rabbits there is $60-70 \%$, in the case of Iberian lynx $65.5 \%$, while the population of the Spanish eagle decreased by $45.5 \%$. These values confirm that the circulating virus has a negative impact on attempts to rebuild the Iberian lynx population in many areas (Monterroso et al., 2016). The presence of RHDV2 strains, due to the increased host panel, may also pose a threat to endangered species of different lagomorphs. This issue should become a subject of interest for researchers in order to prevent the negative impact of the virus on the natural environment (Velarde et al., 2017).

The RHDV2 virus from the unexpected appearance in France in 2010 significantly affected the ordered erudition in the rabbit's haemorrhagic disease. A very important issue is also the wider spectrum of hosts infected with RHDV2. The discussed course of infection caused by this factor, as well as the anatomic changes observed during the disease, indicate that RHDV2 is very difficult to diagnose. This also underlines the reduced mortality in adult rabbits and the prolonged duration of the disease. Difficulties also affect the diagnostic methods developed to quickly and efficiently determine the RHD drive factor. This issue was in fact a priority due to the ineffectiveness of the vaccines previously used against RHDV, which proved ineffective against the RHDV2 virus. This necessitated the development of new specific preventive measures. In addition, the problem is exacerbated by the fact that infections caused by all types of viruses are manifested by the presence of identical symptoms, which excludes the use of disease symptoms as a criterion for strain differentiation. The appearance of a virus has many consequences. One of them is the new system of classification and nomenclature introduced by scientists within the RHD virus. The economic and environmental effects caused by the spread of RHDV2 in the environment are also frightening. There are negative consequences of its presence in Mediterranean ecosystems, as well as in the economic and economic sphere in countries where the rabbit is a key element of the economy. 
The appearance of RHDV2 proves that one should not lose vigilance, but still closely monitor the state of the environment. The noticeable tendency for sudden emergence of new disease factors that cause RHD, which causes more and more difficulties in combating them, means that in the future we should expect another opponent who may again disturb the reconstructed harmony.

\section{References}

Abade Dos Santos, F.A., Carvalho, C., Nuno, O., Correia, J.J., Henriques, M., Peleteiro, M.C., Fevereiro, M., Duarte, M.D. (2017). Detection of rabbit Haemorrhagic disease virus 2 during the wild rabbit (Oryctolagus cuniculus) eradication from the Berlengas archipelago, Portugal. BMC Veterinary Research, 13 (1), 336. DOI: 10.1186/s12917-017-1257-3.

Abrantes, J., Lopes, A.M., Dalton, K.P., Melo, P., Correia, J.J., Ramada, M., Alves, P.C., Parra, F., Esteves, P.J. (2013). New variant of rabbit hemorrhagic disease virus, Portugal, 2012-2013. Emerging Infectious Diseases, 19 (11), 1900-1902. DOI: 10.3201/eid1911.130908.

Abrantes, J., van der Loo, W., Le Pendu, J., Esteves, P.J. (2012). Rabbit haemorrhagic disease (RHD) and rabbit haemorrhagic disease virus (RHDV): a review. Veterinary Research, 43 (1), 12. DOI: 10.1186/1297-9716-43-12.

Baily, J.L., Dagleish, M.P., Graham, M., Maley, M., Rocchi, M.S. (2014). RHDV variant 2 presence detected in Scotland. Veterinary Record, 174 (16), 411. DOI: 10.1136/vr.g2781.

Barcena, J., Guerra, B., Angulo, I., González, J., Valcarcel, F., Mata, C.P., Caston, J.R., Blanco, E., Alejo, A. (2015). Comparative analysis of rabbit hemorrhagic disease virus (RHDV) and new RHDV2 virus antigenicity, using specific virus-like particles. Veterinary Research, 46 (1), 106. DOI: 10.1186/ s13567-015-0245-5.

Bonvehi, C., Ardiaca, M., Montesinos, A., Juan-Salles, C., Gomez, A., Teso, B., Barbero, S., Ferrera, S.E. (2019). Clinicopathologic findings of naturally occurring Rabbit Hemorrhagic Disease Virus 2 infection in pet rabbits. Veterinary Clinical Pathology, 48 (1), 89-95. DOI: 10.1111/vcp.12701.

Calvete, C., Mendoza, M., Sarto, M.P., Bagues, M.P.J., Lujan, L., Molin, J., Calvo, A.J., Monroy, F., Calvo, J.H. (2019). Detection of Rabbit Hemorrhagic Disease Virus GI2RHDV2b in the Mediterranean Pine Vole (Microtus duodecimcostatus) and White-Toothed Shrew (Crocidura russula). Journal of Wildlife Diseases, 55 (2), 467-472. DOI: 10.7589/2018-05-124.

Camarda, A., Pugliese, N., Cavadini, P., Circella, E., Capucci, L., Caroli, A., Legretto, M., Mallia, E., Lavazza, A. (2014). Detection of the new emerging rabbit haemorrhagic disease type 2 virus (RHDV2) in Sicily from rabbit (Oryctolagus cuniculus) and Italian hare (Lepus corsicanus). Research in Veterinary Science, 97 (3), 642-645. DOI: 10.1016/j.rvsc.2014.10.008.

Capucci, L., Cavadini, P., Schiavitto, M., Lombardi, G., Lavazza, A. (2017). Increased pathogenicity in rabbit haemorrhagic disease virus type 2 (RHDV2). Veterinary Record, 180 (17), 426. DOI: 10.1136/ vr.104132.

Carvalho, C.L., Duarte, E.L., Monteiro, M., Botelho, A., Albuquerque, T., Fevereiro M., Henriques, A.M., Barros, S.S., Duarte, M.D. (2017). Challenges in the rabbit haemorrhagic disease 2 (RHDV2) molecular diagnosis of vaccinated rabbits. Veterinary Microbiology, 198, 43-50. DOI: 10.1016/j.vetmic.2016.12.006.

Carvalho, C.L., Silva, S., Gouveia, P., Costa, M., Duarte, E.L., Henriques, A.M., Barros, S.S., Luis, T., Ramos, F., Fagulha, T., Fevereiro, M., Duarte, M. D. (2017). Emergence of rabbit haemorrhagic disease virus 2 in the archipelago of Madeira, Portugal (2016-2017). Virus Genes, 53 (6), 922-926. DOI: 10.1007/s11262-017-1483-6. 
Dalton, K.P., Abrantes, J., Lopes, A.M., Nicieza, I., Alvarez, A.L., Esteves, P.J., Parra, F. (2015). Complete genome sequence of two rabbit hemorrhagic disease virus variant $b$ isolates detected on the Iberian Peninsula. Archives of Virology, 160 (3), 877-881. DOI: 10.1007/s00705-014-2329-3.

Dalton, K.P., Arnal, J.L., Benito, A.A., Chacon, G., Martin, Alonso, J.M., Parra F. (2018). Conventional and real time RT-PCR assays for the detection and differentiation of variant rabbit hemorrhagic disease virus (RHDVb) and its recombinants. Journal of Virological Methods, 251, 118-122. DOI: 10.1016/j. jviromet.2017.10.009.

Dalton, K.P., Nicieza, I. Abrantes, J., Esteves, P.J., Parra, F. (2014). Spread of new variant RHDV in domestic rabbits on the Iberian Peninsula. Veterinary Microbiology, 169 (1-2), 67-73. DOI: 10.1016/j. vetmic.2013.

Dalton, K.P., Nicieza, I., Baseiro, A., Muguerza, M.A., Rosell, J.M., Casais, R., Alvarez, A.L., Parra, F. (2012). Variant rabbit hemorrhagic disease virus in young rabbits, Spain. Emerging Infectious Diseases, 18 (12), 2009-2012. DOI: 10.3201/eid1812.120341.

Dalton, K.P., Nicieza, I., Podadera, A, de Llano, D., Martin Alonso, J.M., de Los Toyos, J.R., Garcia Oceana, M., Vazquez-Villa, F., Velasco, B., Landeta, O., Parra, F. (2018). Fast specific field detection of RHDVb. Transboundary and Emerging Diseases, 65 (1), 232-234. DOI: 10.1111/tbed.12607.

Dalton, K.P., Podadera, A., Granda, V., Nicieza, I., Del Llano, D., Gonzalez, R., de Los Toyos, J.R., Garcia Oceana, M., Vazquez, F., Martin Alonso, J.M., Prieto, J.M., Parra, F., Casais, R. (2018). ELISA for detection of variant rabbit haemorrhagic disease virus RHDV2 antigen in liver extracts. Journal of Virological Methods, 251, 38-42. DOI: 10.1016/j.jviromet.2017.09.019.

Duarte, M., Carvalho, C., Bernardo, S., Barros, S.V., Benevides, S., Flor, L., Monteiro, M., Marques, I., Henriques, M., Barros, S.C., Fagulha, T., Ramos, F., Luis, T., Fevereiro, M. (2015). Rabbit haemorrhagic disease virus 2 (RHDV2) outbreak in Azores: Disclosure of common genetic markers and phylogenetic segregation within the European strains. Infection, Genetics and Evolution, 35, 163-171. DOI: 10.1016/j.meegid.2015.08.005.

Duarte, M., Henriques, M., Barros, S.C., Fagulha, T., Ramos, F., Luis, T., Fevereiro, M., Benevides, S., Flor, L., Barros, S.V., Bernardo, S. (2015). Detection of RHDV variant 2 in the Azores. Veterinary Record, 176 (5), 130. DOI: 10.1136/vr.h497.

Duarte, M.D., Carvalho, C.L., Barros, S.C., Henriques, A.M., Ramos, F., Fagulha, T., Luis, T., Duarte, E.L., Fevereiro, M. (2015). A real time Taqman RT-PCR for the detection of rabbit hemorrhagic disease virus 2 (RHDV2). Journal of Virological Methods, 219, 90-95. DOI: 10.1136/vr.h497.

Dzialo, J., Deptula, W. (2015). Badania filogenetyczne wirusa RHD. Medycyna Weterynaryjna, 71 (1), $5-12$.

Fitzner, A., Niedbalski, W. (2017). Różnorodność wirusa RHD - znaczenie epidemiologiczne, diagnostyczne i immunologiczne. Medycyna Weterynaryjna, 73 (12), 811-818.

Fitzner, A., Niedbalski, W. (2018). Detection of rabbit haemorrhagic disease virus 2 (GI.2) in Poland. Polish Journal of Veterinary Sciences, 21 (3), 451-458. DOI: 10.24425/122618.

Hall, D.C.A. (2002). Molecular and serological studies of Rabbit haemorrhagic disease virus in Otago (Thesis, Doctor of Philosophy). University of Otago. Retrieved from: http://hdl.handle.net/10523/362.

Hall, R.N., Mahar, J.E., Haboury, S., Stevens, V., Holmes, E.C., Strive, T. (2015). Emerging Rabbit Hemorrhagic Disease Virus 2 (RHDVb), Australia. Emerging Infectious Diseases, 21 (12), 2276-2278. DOI: 10.3201/eid2112.151210.

Hall, R.N., Mahar, J.E., Read, A.J., Mourant, R., Piper, M., Huang, N., Strive, T. (2018). A strain-specific multiplex RT-PCR for Australian rabbit haemorrhagic disease viruses uncovers a new recombinant virus variant in rabbits and hares. Transboundary and Emerging Diseases, 65 (2), e444-e456. DOI: 10.1111/tbed.12779. 
Hall, R.N., Peacock, D.E., Kovaliski, J., Mahar, J.E., Mourant, R., Piper, M., Strive, T. (2017). Detection of RHDV2 in European brown hares (Lepus europaeus) in Australia. Veterinary Record, 180 (5), 121. DOI: $10.1136 / v r .104034$.

Le Gall-Recule, G., Lavazza, A., Marchandeau, S., Bertagnoli, S., Zwingelstein, F., Cavadini, P., Martinelli, N., Lombardi, G., Guérin, J.L., Lemaitre, E., Decors, A., Boucher, S., Le Normand, B., Capucci, L. (2013). Emergence of a new lagovirus related to rabbit haemorrhagic disease virus. Veterinary Research, 44, 81. DOI: 10.1186/1297-9716-44-81.

Le Gall-Recule, G., Lemaitre, E., Bertagnoli, S., Hubert, C., Top, S., Decors, A., Marchandeau, S., Guitton, J.S. (2017). Large-scale lagovirus disease outbreaks in European brown hares (Lepus europaeus) in France caused by RHDV2 strains spatially shared with rabbits (Oryctolagus cuniculus). Veterinary Research, 48 (1), 70. DOI: 10.1186/s13567-017-0473-y.

Le Gall-Recule, G., Zwingelstein, F., Boucher S., Le Normand B., Plassiart G., Portejoie Y., Decors A., Bertagnoli S., Guerin, J.L., Marchandeau, S. (2011). Detection of a new variant of rabbit haemorrhagic disease virus in France. Veterinary Record, 168 (5), 137-138. DOI: 10.1136/vr.d697.

Le Gall-Recule, G., Zwingelstein, F., Laurent, S., de Boisseson, C., Portejoie, Y., Rasschaert, D. (2003). Phylogenetic analysis of rabbit haemorrhagic disease virus in France between 1993 and 2000, and the characterisation of RHDV antigenic variants. Archives of Virology, 148 (1), 65-81.

Le Pendu, J., Abrantes, J., Bertagnoli, S., Guitton, J.S., Le Gall-Recule, G., Lopes, A.M., Marchandeau, S., Alda, F., Almeida, T., Celio, A.P., Barcena, J., Burmakina, G., Blanco, E., Calvete, C., Cavadini, P., Cooke, B., Dalton, K., Delibes Mateos, M., Deptula, W., Eden, J.S., Wang, F., Ferreira, C.C., Ferreira, P., Foronda, P., Goncalves, D., Gavier-Widen, D., Hall, R., Hukowska-Szematowicz, B., Kerr, P., Kovaliski, J., Lavazza, A., Mahar, J., Malogolovkin, A., Marques, R.M., Marques, S., Martin-Alonso, A., Monterroso, P., Moreno, S., Mutze, G., Neimanis, A., Niedzwiedzka-Rystwej, P., Peacock, D., Parra, F., Rocchi, M., Rouco, C., Ruvoen-Clouet, N., Silva, E., Silverio, D., Strive, T., Thompson, G., Tokarz-Deptula, B., Esteves, P. (2017). Proposal for a unified classification system and nomenclature of lagoviruses. Journal of General Virology, 98 (7), 1658-1666. DOI: 10.1099/jgv.0.000840.

Leuthold, M.M., Dalton, K.P., Hansman, G.S. (2015). Structural analysis of a rabbit hemorrhagic disease virus binding to histo-blood group antigens. Journal of Virology, 89 (4), 2378-2387. DOI: 10.1128/ JVI.02832-14.

Liu, S.J., Xue, H.P., Pu, B.Q., Quian, N.H. (1984). A new viral disease in rabbits. Animal Husbandry and Veterinary Medicine, 16 (6), 253-255.

Lopes, A.M., Blanco-Aguiar, J, Martin-Alonso, A., Leitao, M., Foronda, P., Mendes, M., Goncealves, D., Abrantes, J., Esteves, P.J. (2018). Full genome sequences are key to disclose RHDV2 emergence in the Macaronesian islands. Virus Genes, 54 (1), 1-4. DOI: 10.1007/s11262-017-1523-2.

Lopes, A.M., Correia, J., Abrantes, J., Melo, P., Ramada, M., Magalhaes, M.J., Alves, P.C., Esteves, P.J. (2014). Is the new variant RHDV replacing genogroup 1 in Portuguese wild rabbit populations? Viruses, 7 (1), 27-36. DOI: 10.3390/v7010027.

Lopes, A.M., Dalton, K.P., Magalhaes, M.J., Parra, F., Esteves, P.J., Holmes, E.C., Abrantes, J. (2015). Full genomic analysis of new variant rabbit hemorrhagic disease virus revealed multiple recombination events. Journal of General Virology, 96, 1309-1319.

Lopes, A.M., Dalton, K.P., Magalhaes, M.J., Parra, F., Esteves, P.J., Holmes, E.C., Abrantes, J. (2015). Full genomic analysis of new variant rabbit hemorrhagic disease virus revealed multiple recombination events. Journal of General Virology, 96 (6), 1309-1319. DOI: 10.1099/vir.0.000070.

Lopes, A.M., Rouco, C., Esteves, P.J., Abrantes, J. (2019). GI.1b/GI.1b/GI.2. recombinant rabbit hemorrhagic disease virus 2 (Lagovirus europaeus/GI.2) in Morocco, Africa. Archives of Virology, 164 (1), 279-283. DOI: 10.1007/s00705-018-4052-y. 
Lopes, A.M., Silverio, D., Magalhaes, M.J., Areal, H., Alves, P.C., Esteves, P.J., Abrantes, J. (2017). Characterization of old RHDV strains by complete genome sequencing identifies a novel genetic group. Scientific Reports, 7 (1), 13599. DOI: 10.1038/s41598-017-13902-2.

Mahar, J.E., Hall, R.N., Peacock, D., Kovaliski, J., Piper, M., Mourant, R., Huang, N., Campbell, S., Gu, X., Read, A., Urakova, N., Cox, T., Holmes, E.C., Strive, T. (2017). Rabbit haemorrhagic disease virus 2 (GI.2) is replacing endemic strains of RHDV in the Australian landscape within 18 months of its arrival. Journal of Virology, 92 (2), e01374-17. DOI: 10.1128/JVI.01374-17.

Martin-Alonso, A., Martin-Carrillo, N., Garcia-Livia, K., Valladares, B., Foronda, P. (2016). Emerging rabbit haemorrhagic disease virus 2 (RHDV2) at the gates of the African continent. Infection, Genetics and Evolution, 44, 46-50. DOI: 10.1016/j.meegid.2016.06.034.

McGowan, S., Choudhury, B. (2016). Update on rabbit haemorrhagic disease virus 2-like variant in Great Britain. Veterinary Record, 178 (26), 662-663. DOI: 0.1136/vr.i3449.

Monterroso, P., Garrote, G., Serronha, A., Santos, E., Delibes-Mateos, M., Abrantes, J., Perez de Ayala, R., Silvestre, F., Carvalho, J., Vasco, I., Lopes, A.M., Maio, E., Magalhaes, M.J., Mills, L.S., Esteves, P.J., Simon, M.A., Alves, P.C. (2016). Disease-mediated bottom-up regulation: An emergent virus affects a keystone prey, and alters the dynamics of trophic webs. Scientific Reports, 6, 36072. DOI: 10.1038/ srep36072.

Muller, C., Ulrich, R., Schinkothe, J., Muller, M., Kollner, B. (2019). Vaccine, 37 (30), 4195-4203. DOI: 10.1016/j.vaccine.2019.04.061.

Mutze, G., De Preu, N., Mooney, T., Koerner, D., McKenzie, D., Sinclair, R., Kovaliski, J., Peacock, D. (2018). Substantial numerical decline in South Australian rabbit populations following the detection of rabbit haemorrhagic disease virus 2. Veterinary Record, 182 (20), 574. DOI: 10.1136/vr.104734.

Neave, M.J., Hall, R.N., Huang, N., McColl, K.A., Kerr, P., Hoehn, M., Taylor, J., Strive, T. (2018). Robust Innate Immunity of Young Rabbits Mediates Resistance to Rabbit Hemorrhagic Disease Caused by Lagovirus Europaeus GI.1 But Not GI.2. Viruses, 10 (9), e512. DOI: 10.3390/v10090512.

Neimanis, A., Larsson Pettersson, U., Huang, N., Gavier-Widen, D., Strive, T. (2018). Elucidation of the pathology and tissue distribution of Lagovirus europaeus GI.2/RHDV2 (rabbit haemorrhagic disease virus 2) in young and adult rabbits (Oryctolagus cuniculus). Veterinary Research, 49 (1), 46. DOI: 10.1186/s13567-018-0540-z.

Neimanis, A.S, Ahola, H., Larsson Pettersson, U., Lopes, A.M., Abrantes, J., Zohari, S., Esteves, P.J., Gavier-Widen, D. (2018). Overcoming species barriers: an outbreak of Lagovirus europaeus GI.2/ RHDV2 in an isolated population of mountain hares (Lepus timidus). BMC Veterinary Research, 14 (1), 367. DOI: 10.1186/s12917-018-1694-7.

Neimanis, A.S., Ahola, H., Zohari, S., Larsson Pettersson, U., Brojer, C., Capucci, L., Gavier-Widen, D. (2018). Arrival of rabbit haemorrhagic disease virus 2 to northern Europe: Emergence and outbreaks in wild and domestic rabbits (Oryctolagus cuniculus) in Sweden. Transboundary and Emerging Diseases, 65 (1), 213-220. DOI: 10.1111/tbed.12650.

Pacho, S., Dahdouh, E., Merino, J., Suarez, M. (2016). Assessment of a Novel Vaccine Against Rabbit Hemorrhagic Disease Virus in Young Rabbits. Viral Immunology, 29 (10), 583-585. DOI: 10.1089/ vim.2016.0093.

Pazdzior, K., Otrocka-Domagala, I., Rotkiewicz, T., Drzewiecka, A. (2011). Wirusowa krwotoczna choroba królików - nowe aspekty immunologiczne i anatomopatologiczne. Życie Weterynaryjne, 86 (11), $865-869$

Peacock, D., Kovaliski, J., Sinclair, R., Mutze, G., Iannella, A., Capucci, L. (2017). RHDV2 overcoming RHDV immunity in wild rabbits (Oryctolagus cuniculus) in Australia. Veterinary Record, 180 (11), 280. DOI: $10.1136 /$ vr.104135. 
Puggioni, G., Cavadini, P., Maestrale, C., Scivoli, R., Botti, G., Ligios, C., Le Gall-Recule, G., Lavazza, A., Capucci, L. (2013). The new French 2010 Rabbit Hemorrhagic Disease Virus causes an RHD-like disease in the Sardinian Cape hare (Lepus capensis mediterraneus). Veterinary Research, 44, 96. DOI: 10.1186/1297-9716-44-96.

Rahali, N., Sghaier, S., Kbaier, H., Zanati, A., Bahloul, C. (2019). Genetic characterization and phylogenetic analysis of rabbit hemorrhagic disease virus isolated in Tunisia from 2015 to 2018. Archives of Virology, 164 (9), 2327-2332. DOI: 10.1007/s00705-019-04311-z.

Rouco, C., Abrantes, J., Serronha, A., Lopes, A.M., Maio, E., Magalhaes, M.J., Blanco, E., Barcena, J., Esteves, P.J., Santos, N., Alves, P.C., Monterroso, P. (2018). Epidemiology of RHDV2 (Lagovirus europaeus/GI.2) in free-living wild European rabbits in Portugal. Transboundary and Emerging Diseases, 65 (2), e373-e382. DOI: 10.1111/tbed.12767.

Rouco, C., Aguayo-Adan, J.A., Santoro, S., Abrantes, J., Delibes-Mateos, M. (2019). Worldwide rapid spread of the novel rabbit haemorrhagic disease virus (GI2RHDVb). Transboundary and Emerging Diseases, 66 (4), 1762-1764. DOI: 10.1111/tbed.13189.

Silverio, D., Lopes, A.M., Melo-Ferreira, J., Magalhães, M.J., Monterroso, P., Serronha, A., Maio, E., Alves, P.C., Esteves, P.J., Abrantes, J. (2018). Insights into the evolution of the new variant rabbit haemorrhagic disease virus (GI.2) and the identification of novel recombinant strains. Transboundary and Emerging Diseases, 65 (4), 983-992. DOI: 10.1111/tbed.12830.

Simpson, V., Everest, D., Westcott, D. (2014). RHDV variant 2 and Capillaria hepatica infection in rabbits. Veterinary Record, 174 (19), 486. DOI: 10.1136/vr.g3164.

Tokarz-Deptula, B., Deptula, W., Kesy, A. (2002). Pomór królików ze szczególnym uwzględnieniem zjawisk odpornościowych. Medycyna Weterynaryjna, 58 (7), 497-500.

Velarde, R., Cavadini, P., Neimanis, A., Cabezón, O., Chiari, M., Gaffuri A., Lavin, S., Grilli, G., GavierWiden, D., Lavazza, A., Capucci, L. (2017). Spillover Events of Infection of Brown Hares (Lepus europaeus) with Rabbit Haemorrhagic Disease Type 2 Virus (RHDV2) Caused Sporadic Cases of an European Brown Hare Syndrome-Like Disease in Italy and Spain. Transboundary and Emerging Diseases, 64 (6), 1750-1761. DOI: 10.1111/tbed.12562.

Westcott, D.G., Frossard, J.P., Everest, D., Dastjerdi, A., Duff, J.P., Steinbach, F., Choudhury, B. (2014). Incursion of RHDV2-like variant in Great Britain. Veterinary Record, 174 (13), 333. DOI: 10.1136/ vr.g2345.

Xue, J., Hu B., Fan, Z., Wang, F., Song, Y., Wei, H., Liu, X., Qiu, R., Xu, W., Yuan, W. (2016). A new variant of rabbit hemorrhagic disease virus G2-like strain isolated in China. Virus Research, 215, 20-24. DOI: 10.1016/j.virusres.2016.01.018.

Cite as: Bębnowska, D., Niedźwiedzka-Rystwej, P. (2019). Characteristics of a new variant of rabbit haemorrhagic disease virus - RHDV2. Acta Biologica, 26, 83-97. DOI: 10.18276/ab.2019.26-08. 